\title{
Age and growth of blotched picarel (Spicara maena Linnaeus, 1758) in the Sea of Marmara and Northern Aegean Sea
}

\section{Marmara ve Ege Deniz'lerindeki İzmarit balığı'nın (Spicara maena Linnaeus, 1758) yaş ve büyüme özellikleri}

\author{
Burak Saygılı* • Ali İşmen • Mukadder Arslan İhsanoğlu \\ Canakkale Onsekiz Mart University, Marine Science and Technology Faculty, Çanakkale, Turkey \\ *Corresponding author: buraksaygili@gmail.com
}

How to cite this paper:

Saygll, B., İ̧men,A. \& Arslan İhsanoğlu,M. (2016). Age and growth of blotched picarel (Spicara maena Linnaeus, 1758) in the Sea of Marmara and Northern Aegean Sea. Ege Journal of Fisheries and Aquatic Sciences, 33(2): 143-149. doi: 10.12714/egejfas.2016.33.2.08

\begin{abstract}
The aim of this study was determining of some population parameters of Spicara maena in the Sea of Marmara and North Aegean Sea. Samples of S. maena were collected from commercial fishing, gillnet/trammel net and line fishing, between February-October 2013 in the Northern Aegean Sea (Dikili, Altınoluk, Küçükkuyu) and the Sea of Marmara (Karabiga, Bandırma, Tekirdağ). A total of $323 \mathrm{~S}$. maena specimens were analysed. The total length of the specimens ranged from 8.4 to $18.8 \mathrm{~cm}$. The length-weight relationships for the Sea of Marmara and the Northern Aegean Sea were $a=0.0030, b=3.53, S E_{b}=0.080$ and $a=0.0100$, $b=3.06, \mathrm{SE}_{b}=0.120$ respectively. The $b$ values showed that the growth of $S$. maena in the Northern Aegean Sea was isometric while the sample in the Sea of Marmara showed positively allometric growth. Fish aged 1-4 years in the Sea of Marmara and 2-6 years in the North Aegean Sea were present in the samples. Growth in length including both sexes was expressed using the von Bertalanffy equation, $L_{\infty}=17.17 \mathrm{~cm}, k=0.52 \mathrm{y}, \mathrm{t}_{0}=-1.04 \mathrm{y}^{-1}$ in the Sea of Marmara and $L_{\infty}=18.71$ $\mathrm{cm}, \mathrm{k}=0.35 \mathrm{y}, \mathrm{t}_{0}=-1.98 \mathrm{y}^{-1}$ in the Northern Aegean Sea. The otolith length-total length relationships in the Sea of Marmara and the Northern Aegean Sea were $\mathrm{OL}=0.301 \times \mathrm{TL}+1.049$ and $\mathrm{OL}=0.249 \times \mathrm{TL}+1.885$, respectively.
\end{abstract}

Keywords: Spicara maena, otolith, length-weight relationship

Öz: Bu çalışmanın amacı Marmara Denizi ve Ege Denizi'nde Spicara maena'nın bazı populasyon parametrelerini belirlemekti. S. maena örnekleri Şubat-Ekim 2013 tarihleri arasında ticari balıkçıık, fanyalı ağlar ve olta balıkçılığı ile Kuzey Ege Denizi (Dikili, Altınoluk ve Küçükkuyu) ve Marmara Denizinden (Karabiga, Bandırma ve Tekirdağ) elde edilmiştir. Çalışmada elde edilen toplam 323 adet S. maena bireyine ait total boy değerinin 8.4-18.4 cm arasında olduğu belirlenmiştir. Boy-ağırlık ilişki parametreleri Marmara Denizi için $a=0,003, b=3,532$ ve Kuzey Ege Denizi için $a=0,010, b=3,063$ olarak hesaplamıştır. Buna göre $S$. maena'nın Kuzey Ege Denizinde izometrik ve Marmara Denizinde ise pozitif allometrik büyüme özelliği sergilediği görülmüştür. Marmara Denizindeki bireylerin 1-4 yaş arasında ve Kuzey Ege Denizindeki bireylerin ise 2-6 yaş arasında dağılım gösterdiği belirlenmiştir. Her iki cinsiyet dahil olmak üzere von Bertalanfy büyüme parametresi değerleri Marmara Denizinde $\mathrm{L}_{\infty}=17,17 \mathrm{~cm}, \mathrm{k}=0,52$ yıl, $\mathrm{t}_{0}=-1,04$ yıl-1 ve Kuzey Ege Denizinde $\mathrm{L}_{\infty}=18,71 \mathrm{~cm}, \mathrm{k}=0,35 \mathrm{yll}, \mathrm{t}_{0}=-1,98 \mathrm{yll}-1 \mathrm{olarak}$ hesaplanmıştır. Otolit boyu-total boy ilişkisi Marmara Denizi için $O L=0,301 \times T L+1,049$ ve Kuzey Ege Denizi için $O L=0,249 \times T L+1,885$ olarak tahmin edilmiştir.

Anahtar kelimeler: Spicara maena, otolit, boy-ağırlık ilişkisi

\section{INTRODUCTION}

Spicara maena, which is the member of the Sparidae family, is found generally in the rocky parts of the seas with Posidonia, and in deep muddy areas (Tortonese, 1986). It is commonly observed in the Mediterranean, Black Sea, Portugal, Morocco and Canary Island waters (Jardas, 1996) in $170 \mathrm{~m}$ depths (Miller and Loates, 1997). Spicara maena species has a wide body structure and is also called as blotched picarel (Akşıray, 1987; Bat et al., 2008; Can and Bilecenoğlu, 2005). A beamy spot in the sides of their bodies with a color changing from grey to brown and some stripes on their backs are the characteristics of them (Can and Bilecenoğlu, 2005). It has vomer teeth and 2-6 pieces long canine-formed teeth (Ekingen, 2004). Picarel species exhibits protogynous hermaphroditisym characteristics (İşmen, 1995; Şahin and Genç, 1999; Yeldan et al., 2003; Matic-Skoko et al., 2004; Can and Bilecenoğlu, 2005). It has the habit of feeding in an omnivorous manner mainly feeds on crustacean (crab, shrimp, isopods, etc.), mollusks (mussel, gastropods, cephalopods, etc.), and zooplanktons (Can and Bilecenoğlu, 2005).

Studies on picarel species in the literature are mostly on the 
biological properties of the species (growth, reproduction, length-weight relations) in Eastern Mediterranean, Black Sea and Mid-Aegean (Akşıray, 1987; İşmen, 1995; Şahin and Genç, 1999; Mater et al., 2001; Yeldan et al., 2003; Ercan et al., 2006; Avşar et al., 2007; Çiçek et al. 2007; Kalaycı et al., 2007; Çicek and Avşar 2010; Soykan, 2010). On the other hand, there are no studies conducted on the biological properties of the picarel species in the Northern Aegean Sea and the Sea of Marmara.

In this study, the length-weight relation, otolith length-total length relationship, age and growth parameters of the S. maena were estimated from the Sea of Marmara and Northern Aegean Sea. The results of the study are important in that they contribute to the previous studies and also help to produce strategies and policies for sustainable production.

\section{MATERIAL AND METHODS}

Samples of Spicara maena were collected from commercial fishing, line fishing, gillnet and trammel net and between February-October 2013 in the Northern Aegean Sea (Dikili, Altınoluk and Küçükkuyu) and the Sea of Marmara (Karabiga, Bandırma and Tekirdağ) (Figure 1).

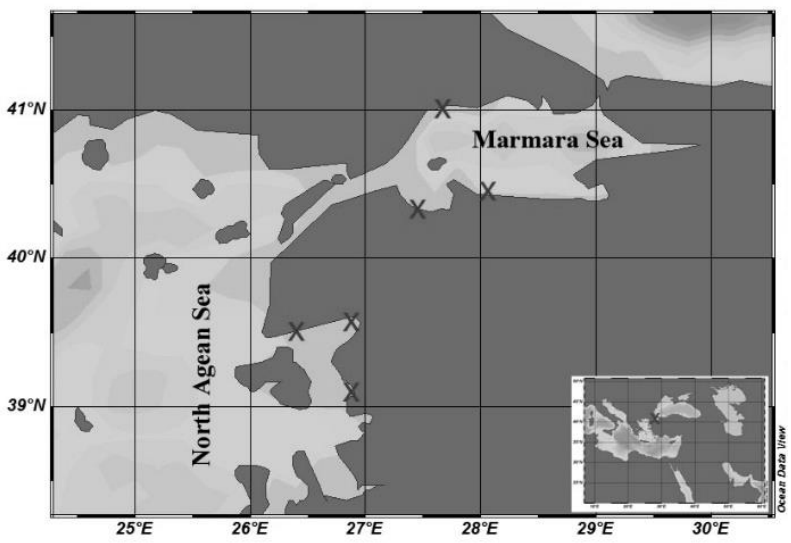

Figure 1. Sampling stations of Spicara maena in the Sea of Marmara and North Aegean Sea

Total lengths ( $T L$ ) of each speciemens were measured to the nearest $1 \mathrm{mmand}$ weighted to the nearest $0.01 \mathrm{~g}$. The gender determination in fish was made with macroscopic and microscopic examination from the gonads (Nikolsky, 1963; Çelikkale, 1991; Avşar, 1998; Aslan, 2009). Male to female ratio was estimated as the ratio of the total number of females to the number of males plus females (Gelman et al., 2004).

The length-weight relation of the individuals was calculated by using the $W=a^{*} L^{b}$ equation. $W$ : total weight $(g), L$ : total length (cm), a and b: regression coefficients (Ricker, 1975). And t-test was applied to determine if the $b$ value was significantly different from the isometric expected value of 3 (Pauly, 1984).

In order to age determination sagittal otoliths in both sides of the head were removed with thin forceps and were cleaned from the tissue particles with 10\% alcohol, they were kept in
Eppendorf tubes. The right otoliths were used to age determination and measured under Olympus SZX 16 stereo zoom microscope at $10 x$ with reflected lights against dark background and image analysis program. The lengths of otoliths were measured over digital images. The opaque and hyaline age rings were measured and the ages of the individuals were determined (Figure 2).

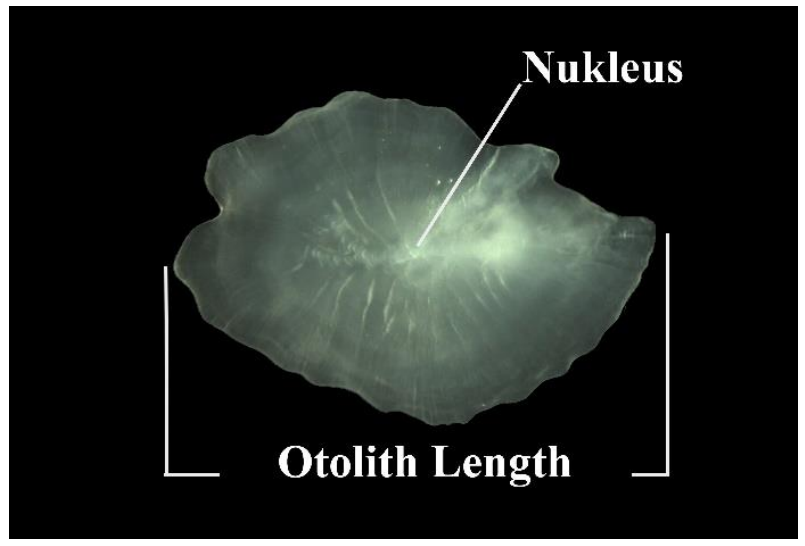

Figure 2. Otolith length and otolith width

The relation between total lengths and otolith lengths (OL) were determined with linear regression analysis $(O L=a+b * T L)$. $\mathrm{OL}$ : otolith length, $\mathrm{a}$ and $\mathrm{b}$ are related parameters (Sparre and Venema, 1998).

The growth parameters were measured by using von Bertalanffy Growth Model (Ricker, 1975). $\mathrm{L}_{t}=\mathrm{L}_{\infty}\left[1-\mathrm{e}^{-k(\mathrm{t}-\mathrm{t} 0)}\right], \mathrm{L}_{\mathrm{t}}$ : The average length of the fish at age $t(\mathrm{~cm}), L_{\infty}$ : Maximum length a fish can reach theoretically at infinity $(\mathrm{cm}), \mathrm{k}$ : Growth coefficient (year-1), t: Age (year), to: Theoretical age of the fish before they are hatched (year).

The growth constants calculated in this study and the constants calculated in other studies were compared by using the Munro's Phi index and the t test. When this test was being applied, the growth constants $(k)$ and $\left(L_{\infty}\right)$ values, which were obtained from the previous studies on the same species, were used. For each of these values, $\varphi^{\prime}$ values were calculated using $\varphi^{\prime}=\log (k)+2 \times \log \left(L_{\infty}\right)$ formula. The hypothesis assuming that there were no differences between the growth constants calculated and the other constants in previous studies was accepted ( $\mathrm{t}_{\mathrm{s}}<\mathrm{t}_{\mathrm{t}}$ ) (Pauly and Munro, 1984; Avşar, 1998).

\section{RESULTS}

\section{Length distribution}

A total of 168 speciemens of Spicara maena from North Aegean Sea and 155 from the Sea of Marmarawere sampled between February-October 2013. Total length and weight ranged from 8.4 to $18.1 \mathrm{~cm}$ with the mean of $13.8 \pm 0.10 \mathrm{~cm}$ and 5.4 to $82.3 \mathrm{~g}$ with the mean of $35.1 \pm 0.09 \mathrm{~g}$ for Sea of Marmara. Total length and weight ranged from 12.8 to $18.8 \mathrm{~cm}$ with mean of $15.2 \pm 0.94 \mathrm{~cm}$ and 19.6 to $97.7 \mathrm{~g}$ with the mean $44.1 \pm 1.05 \mathrm{~g}$ for North Aegean Sea, respectively (Table 1, Figure 3). 
Table 1. Length and weight of Spicara maena according to the regions

\begin{tabular}{cllllllll}
\hline Region & Sex & $L_{\text {mean }}(\mathbf{c m})$ & $L_{\text {Min-Max }}(\mathbf{c m})$ & SE & W $_{\text {mean }}(\mathbf{g})$ & $\mathbf{W}_{\text {Min-Max }}(\mathbf{g})$ & SE & $\mathbf{n}$ \\
\hline \multirow{3}{*}{ Sea of Marmara } & Female & 13.7 & $10.6-16.8$ & 0.21 & 33.4 & $13.2-68.3$ & 1.89 & 47 \\
& Male & 13.9 & $8.4-18.1$ & 0.14 & 35.9 & $5.4-82.3$ & 1.25 & 64 \\
& Total & 13.8 & $8.4-18.1$ & 0.10 & 35.1 & $5.4-82.3$ & 0.94 & 155 \\
\cline { 2 - 8 } North Aegean & Female & 14.6 & $12.8-16.8$ & 0.14 & 40.4 & $23.1-60.4$ & 1.13 & 50 \\
Sea & Male & 15.6 & $13.4-18.8$ & 0.18 & 50.2 & $24.8-97.7$ & 2.37 & 62 \\
& Total & 15.2 & $12.8-18.8$ & 0.09 & 44.1 & $19.6-97.7$ & 1.05 & 168 \\
\hline
\end{tabular}

*: Female, Male and unsexed individuals, n: number of specimens, SE: standard error.

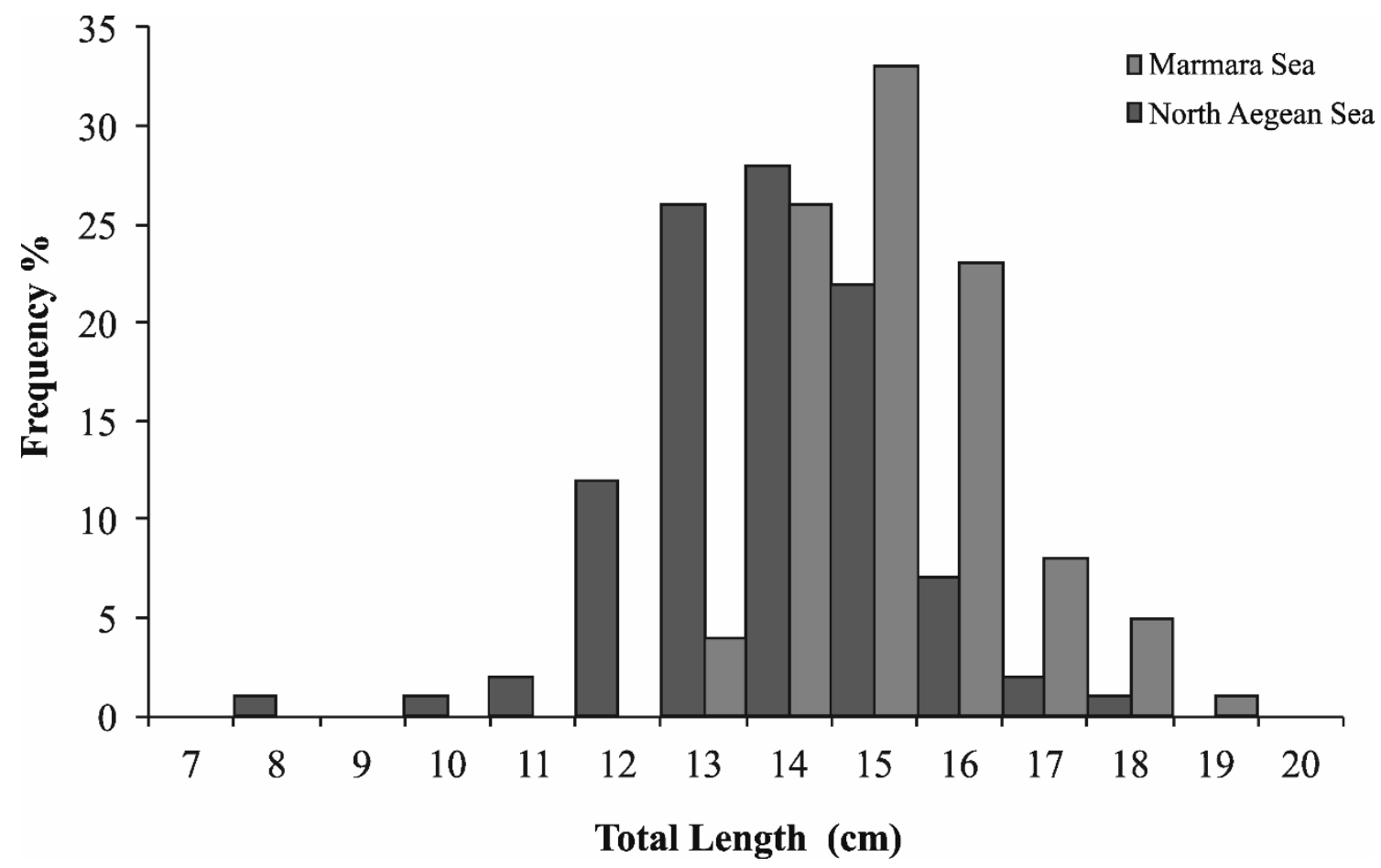

Figure 3. Length-frequency for Spicara maena according to the regions

The length distribution of $\mathrm{S}$. maena indicated that the most frequent size classes were $14 \mathrm{~cm}$ in the Sea of Marmara and $15 \mathrm{~cm}$ in the North Aegean Sea (Figure 3). The sex ratio was calculated as 1:0.73 and 1:0.81 males to females of Sea of Marmara and Northern Aegean Sea, respectively. The overall sex-ratio was not significantly different from the expected 1:1 ratio $\left(p>0.05, X^{2}\right)$.

\section{Length-weight relationship}

The length-weight relationship for S. maena from the Sea of Marmara and North Aegean Sea were determined as $W=0.003 \times L^{3.532}\left(R^{2}=0.914\right)$ and $W=0.010 \times L^{3.063}\left(R^{2}=0.781\right)$, respectively (Figure 4). It was determined that speciemens from the Sea of Marmara showed positive allometric growth $(b>3$, $p<0.05)$ and the ones from North Aegean Sea showed isometric growth $(b=3, p>0.05)$.
It was determined that there is a statistically significant difference between the length-weight relationships of the $S$. maena individuals from the Sea of Marmara and North Aegean Sea (ANCOVA, $p<0.05)$.

\section{Otolith length-total length relationship}

The otolith lengths of the S. maena individuals from the Sea of Marmara varied between 3.8 and $6.7 \mathrm{~mm}$, whereas, the otolith lengths of the S. maena individuals from North Aegean Sea varied from 4.6 to $6.6 \mathrm{~mm}$.

It was determined that there is a linear relation between the total lengths of the samples and the otolith lengths. The otolith lengths-total lengths relationship between the individuals from of the Marmara and North Aegean Sea are $\mathrm{OL}=0.301^{*} \mathrm{TL}+$ 1.049 ve $\mathrm{OL}=0.249^{*} \mathrm{TL}+1.885$, respectively (Figure 5 ). 


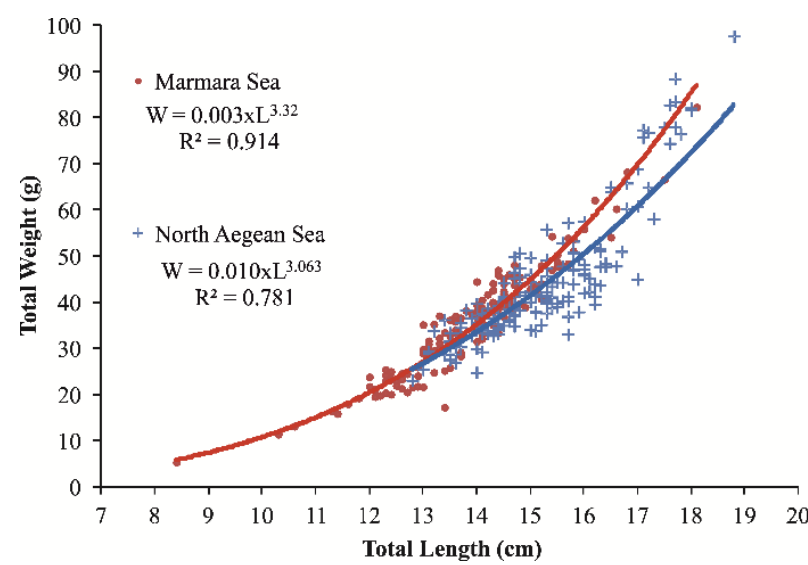

Figure 4. Length-weight relationship of Spicara maena according to the regions

\section{Age composition}

When the age distribution of the $S$. maena individuals are examined, it was determined that the samples in the Sea of Marmara Sea showed a distribution between 1-4 years of age, while the ones from North Aegean Sea showed a distribution between 2-6 years of age (Table 2). The dominant age group in both seas was determined as 2 .

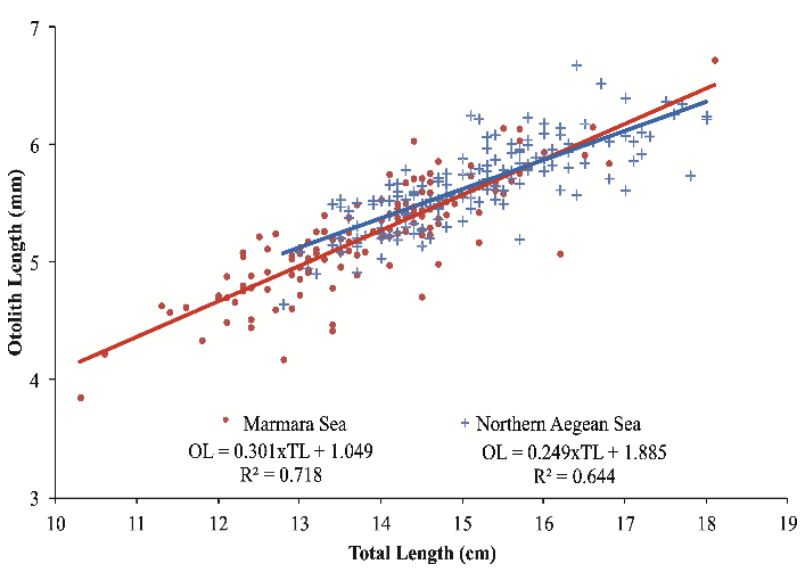

Figure 5. The otolith lengths-total lengths relationships between the individuals from the Sea of Marmara and Northern Aegean Sea

\section{Growth Parameters}

The growth parameters of the $S$. maena individuals in the Sea of Marmara and Northern Aegean Sea were determined as:

$L_{\infty}=17.17 \mathrm{~cm}, k=0.52 \mathrm{y}, \mathrm{t}_{0}=-1.04 \mathrm{y}^{-1}$ and $\mathrm{L}_{\infty}=18.71 \mathrm{~cm}$ $\mathrm{k}=0.35 \mathrm{y}, \mathrm{t}_{0}=-1.98 \mathrm{y}^{-1}$ years, respectively (Figure 6 and 7 ).

Table 2. Length-age distribution of Spicara maena according to the regions

\begin{tabular}{ccccc|cccc}
\hline \multicolumn{3}{c}{ Sea of Marmara } \\
\hline Age & $\mathbf{n}$ & $\mathbf{n} \%$ & Length Range $(\mathbf{c m})$ & Mean length $(\mathbf{c m})$ & $\mathbf{n}$ & $\mathbf{n} \%$ & Length Range $(\mathbf{c m})$ & Mean length $(\mathbf{c m})$ \\
\hline $\mathbf{0}$ & - & & - & - & - & - & - \\
$\mathbf{1}$ & 7 & 5 & $10.3-12$ & $11.29 \pm 0.23$ & - & - & $14.18 \pm 0.06$ \\
$\mathbf{2}$ & 98 & 73 & $12-15.4$ & $13.58 \pm 0.08$ & 73 & 44 & $12.8-15.3$ & $15.45 \pm 0.06$ \\
$\mathbf{3}$ & 22 & 16 & $14-16.5$ & $15.12 \pm 0.12$ & 57 & 35 & $14.5-16.6$ & $16.28 \pm 0.13$ \\
$\mathbf{4}$ & 8 & 6 & $14.8-16.8$ & $15.87 \pm 0.23$ & 17 & 10 & $15.1-17.3$ & $17.34 \pm 0.12$ \\
$\mathbf{5}$ & - & & - & - & 15 & 9 & $16.1-18.0$ & $17.87 \pm 0.58$ \\
$\mathbf{6}$ & - & - & - & 3 & 2 & $16.8-18.8$ & \\
\hline
\end{tabular}

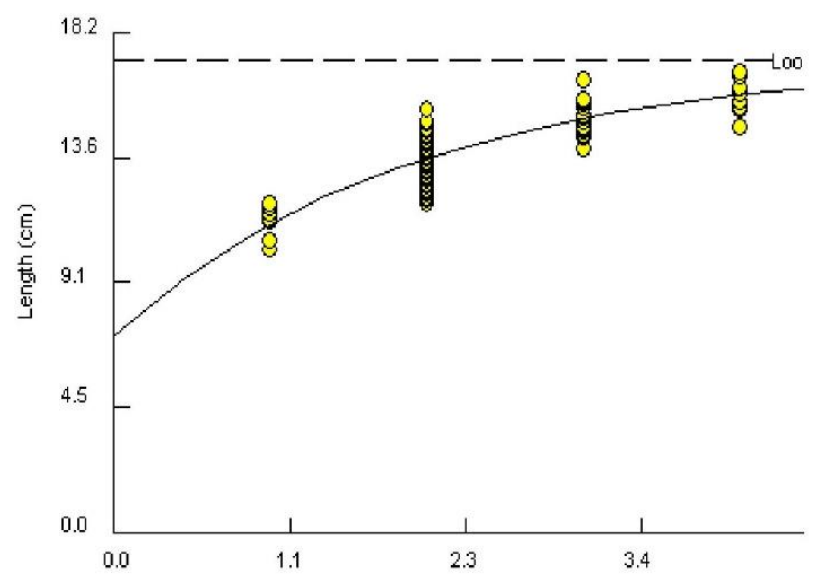

Figure 6. Growth curve of Spicara maena in the Sea of Marmara

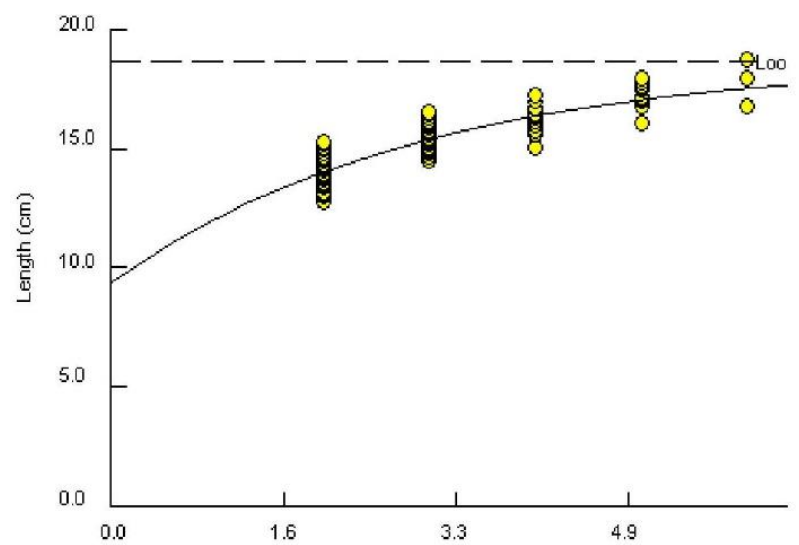

Figure 7. Growth curve of Spicara maena in Northern Aegean Sea 


\section{DISCUSSION}

Length-weight relationship parameters of S.maena were determined as $a=0.003, b=3.532$ in the Sea of Marmara and $a=0.010, b=3.063$ were in the Aegean Sea, respectively. There were only one study about length-weight relationship of S.maena in the Sea of Marmara (Demirel and Murat Dalkara, 2012).
The parameters calculated as $a=0.003, b=3.532$ and growth type were isometric contrary to present study. And other studies in the Aegean Sea there were similarities and differences between length-weight relationship values determined in the present study. It is considered that the difference between length-weight relationship values and growth types stem from the region, time, and the number of the individuals (Table 3).

Table 3. Previously reported length-weight relationship parameters of Spicara maena in Aegean and Mediterranean

\begin{tabular}{|c|c|c|c|c|c|c|c|c|}
\hline References & Region & $\mathbf{N}$ & Sex & $\begin{array}{l}L_{\min }-\max \\
(\mathrm{cm})\end{array}$ & a & b & $\mathrm{SE}_{\mathrm{b}}$ & GP \\
\hline Mytilineou et al. (1991) & Greece & 628 & $F$ & $7.0-15.5$ & 0.013 & 3.040 & - & - \\
\hline Mytilineou et al. (1991) & Greece & 359 & M & $7.5-15.5$ & 0.010 & 3.112 & - & - \\
\hline Petrakis and Stergiou (1995) & Greece & 33 & $\mathrm{~F}$ & $11.7-18.4$ & 0.001 & 2.663 & 0.160 & A- \\
\hline Petrakis and Stergiou (1995) & Greece & 441 & M & $11.9-17.7$ & 0.001 & 3.389 & 0.054 & $A+$ \\
\hline Dulcic adn Kraljevic (1996) & E. Adriatic & 220 & - & $14.5-27.5$ & 0.043 & 3.037 & - & - \\
\hline Merella et al. (1997) & Spain & 11 & - & $15.3-18.2$ & 0.015 & 2.900 & - & - \\
\hline Dulcic et al. (2000) & E. Adriatic & 1130 & $\mathrm{~T}$ & $7.8-27.5$ & 0.009 & 3.120 & 0.025 & $A+$ \\
\hline Mater et al. (2001) & Aegean Sea & 240 & $\mathrm{~F}$ & $9.2-14.9$ & 0.116 & 2.163 & - & - \\
\hline Mater et al. (2001) & Aegean Sea & 172 & M & $11.3-15.5$ & 0.046 & 2.566 & - & - \\
\hline Mater et al.. (2001) & Aegean Sea & 412 & $\mathrm{~T}$ & $9.2-15.5$ & 0.041 & 2.594 & - & - \\
\hline Moutopoulos and Stergiou (2002) & Aegean Sea & 61 & $\mathrm{~T}$ & $15.5-21.0$ & 0.036 & 2.627 & 0.239 & I \\
\hline Moutopoulos and Stergiou (2002) & Aegean Sea & 721 & $\mathrm{~T}$ & $14.3-23.5$ & 0.009 & 3.155 & 0.041 & $A^{+}$ \\
\hline Moutopoulos andStergiou (2002) & Aegean Sea & 808 & $\mathrm{~T}$ & $14.3-26.0$ & 0.010 & 3.096 & 0.041 & $A+$ \\
\hline Dulcic and Glamuzina (2003) & E. Adriatic & 33 & - & 7.8-15.8 & 0.010 & 3.076 & - & - \\
\hline Borges et al. (2003) & Portugal & 45 & - & $10.2-19.2$ & 0.010 & 3.076 & - & - \\
\hline Valle et al. (2003) & Spain & 92 & - & $4.7-21.2$ & 0.006 & 3.262 & - & - \\
\hline Çiçek et al. (2006) & Babadil L. & 1381 & - & $4.2-17.8$ & 0.009 & 3.115 & 1.129 & $A^{+}$ \\
\hline Karakulak et al. (2006) & N. Aegean Sea & 133 & $\mathrm{~F}$ & $11.5-18.1$ & 0.004 & 3.358 & 1.303 & $\mathrm{~A}^{+}$ \\
\hline Karakulak et al. (2006) & N. Aegean Sea & 142 & M & $13.5-22.0$ & 0.002 & 3.678 & 1.132 & $A+$ \\
\hline Karakulak et al. (2006) & N. Aegean Sea & 830 & $\mathrm{~T}$ & $11.0-22.0$ & 0.003 & 3.505 & 1.066 & $A^{+}$ \\
\hline Karakulak et al. (2006) & N. Aegean Sea & 50 & $\mathrm{~T}$ & $12.6-21.9$ & 0.018 & 2.867 & 1.103 & A- \\
\hline Karakulak et al. (2006) & N. Aegean Sea & 75 & $\mathrm{~T}$ & $13.1-20.3$ & 0.002 & 3.696 & 0.823 & $A^{+}$ \\
\hline Karakulak et al. (2006) & N. Aegean Sea & 172 & $\mathrm{~T}$ & $11.5-22.0$ & 0.004 & 3.354 & 1.102 & $A^{+}$ \\
\hline Karakulak et al. (2006) & N. Aegean Sea & 533 & $\mathrm{~T}$ & $11.0-21.3$ & 0.007 & 3.178 & 1.039 & $A+$ \\
\hline Çiçek et al. (2007) & E. Mediterranean & 1078 & $\mathrm{~F}$ & - & 0.008 & 3.139 & 0.016 & $A+$ \\
\hline Çiçek et al. (2007) & E. Mediterranean & 302 & $M$ & - & 0.010 & 3.065 & 0.012 & $A+$ \\
\hline Çiçek et al. (2007) & E. Mediterranean & 1380 & $\mathrm{~T}$ & $5.3-17.8$ & 0.008 & 3.137 & 0.010 & $A^{+}$ \\
\hline İşmen et al. (2007) & N. Aegean Sea & 353 & $\mathrm{~T}$ & $8.8-17.8$ & 0.001 & 3.010 & 0.033 & । \\
\hline Sangun et al. (2007) & E. Mediterranean & 298 & - & $8.7-17.1$ & 0.008 & 3.093 & 0.082 & $A^{+}$ \\
\hline Gökçe et al. (2010) & E. Mediterranean & 17 & - & $13.3-17.9$ & 0.022 & 2.800 & 0.220 & 1 \\
\hline Soykan et al. (2010) & Aegean Sea & 1766 & $\mathrm{~F}$ & - & 0.011 & 3.000 & 0.020 & I \\
\hline Soykan et al. (2010) & Aegean Sea & 398 & M & - & 0.011 & 2.990 & 0.033 & I \\
\hline Soykan et al. (2010) & Aegean Sea & 2547 & $\mathrm{~T}$ & $7.5-20.0$ & 0.011 & 3.020 & 0.012 & I \\
\hline Demirel and Murat Dalkara (2012) & Sea of Marmara & 175 & $\mathrm{~T}$ & $14.3-10.4$ & 0.010 & 3.025 & 0.096 & । \\
\hline Bolognini et al. (2013) & Adriatic Sea & 1810 & $\mathrm{~T}$ & $8.5-25.5$ & 0.007 & 3.156 & 0.021 & $\mathrm{~A}^{+}$ \\
\hline Present study & Sea of Marmara & 155 & $\mathrm{~T}$ & $8.4-18.1$ & 0.003 & 3.532 & 0.080 & $\mathrm{~A}^{+}$ \\
\hline Present study & N. Aegean Sea & 168 & $\mathrm{~T}$ & $12.8-18.8$ & 0.010 & 3.063 & 0.120 & I \\
\hline
\end{tabular}

F:female, M:male, T:total specimens, GP: Growth pattern, A+: Positive allometric, A-: Negative allometric, I: Isometric, $a=$ intercept, $b=$ slope of the regression, $\mathrm{r} 2$ = coefficient of determination 
It was determined that the individuals sampled from the Sea of Marmara were between the ages I-IV; and the ones from North Aegean Sea between II-VI. Mostly the individuals were between the ages of 2 and 3 in both regions. Mytilineou and Papaconstantinou (1991) conducted a study in Patraikos Gulf, and reported that the $S$. maena (syn. $S$. flexuosa) individuals were between the ages of I-V; Mater et al. (2001) conducted a study in Izmir Gulf and reported that the age distribution of $S$. maena (syn. S. flexuosa) was between I-IV; Çiçek et al. (2007) conducted a study in Babadıllimanı and reported that the age group of the $S$. maena individuals was between I-V. It was determined that there were similarities between the age groups determined in the present study and the ones determined in previous studies. It is considered that the reason for the biggest and lowest age groups being different from the ones determined in this study stems from the time and regions of the studies being different and the fishing tools being selective.

The von Bertalanfy growth parameters of the $S$. maena individuals in this study were determined as $L_{\infty}=17.17 \mathrm{~cm}$ $\mathrm{K}=0.52 \mathrm{y}, \mathrm{t}_{0}=-1.04 \mathrm{y}^{-1} ; \mathrm{L}_{\infty}=18.71 \mathrm{~cm}, \mathrm{~K}=0.35 \mathrm{y}, \mathrm{t}_{0}=-1.98 \mathrm{y}^{-1}$ in the Sea of Marmara and North Aegean Sea, respectively. It was also determined that the phi-prime $\left(\varnothing^{\prime}\right)$ index calculated for the growth parameters varied between 1.92 and 2.15. It was determined that there was not a statistically significant difference between the growth performance indices calculated in this study and the ones determined in previous studies according to Munro's Phi Test ( $\left.t_{s}<t, p>0.05\right)$ (Table 4).

Table 4. Reported growth parameters of Spicara maena in Aegean and Mediterranean

\begin{tabular}{|c|c|c|c|c|c|c|}
\hline References & Region & Sex & $\mathrm{L}_{\infty}(\mathrm{cm})$ & $\mathrm{K}$ & $t_{0}$ & $\varnothing^{\prime}$ \\
\hline Hattour et al. (1985) & Mediterranean & - & 24.7 & 0.17 & -0.97 & 2.00 \\
\hline Mytilineou et al. (1991) & Mediterranean & $\mathrm{F}$ & 16.3 & 0.31 & -1.89 & 1.92 \\
\hline Mytilineou et al. (1991) & Mediterranean & $\mathrm{F}$ & 17.5 & 0.34 & -1.90 & 2.02 \\
\hline Rizkalla (1997) & E. Mediterranean & $\mathrm{F}$ & 23.8 & 0.20 & -2.32 & 2.05 \\
\hline Rizkalla (1997) & E. Mediterranean & M & 26.3 & 0.18 & -2.29 & 2.09 \\
\hline Dulcic et al. (2000) & E. Adriatic & $T$ & 22.8 & 0.28 & -0.79 & 2.16 \\
\hline Mater et al. (2001) & Aegean Sea & $\mathrm{F}$ & 17.1 & 0.31 & -0.64 & 1.96 \\
\hline Mater et al. (2001) & Aegean Sea & M & 18.3 & 0.25 & -2.63 & 1.92 \\
\hline Mater et al. (2001) & Aegean Sea & $\mathrm{T}$ & 19.5 & 0.20 & -0.40 & 1.88 \\
\hline Çiçek et al. (2007) & E. Mediterranean & $\mathrm{F}$ & 25.4 & 0.27 & -0.35 & 2.24 \\
\hline Çiçek et al. (2007) & E. Mediterranean & M & 37.2 & 0.01 & -3.39 & 1.14 \\
\hline Çiçek et al. (2007) & E. Mediterranean & $\mathrm{T}$ & 21.7 & 0.39 & -0.14 & 2.26 \\
\hline Soykan et al. (2010) & Aegean Sea & $\mathrm{T}$ & 22.0 & 0.26 & -1.17 & 2.09 \\
\hline Present study & Marmara Sea & $\mathrm{T}$ & 17.2 & 0.52 & -1.04 & 2.18 \\
\hline Present study & N. Aegean Sea & $T$ & 18.7 & 0.20 & -1.98 & 2.09 \\
\hline
\end{tabular}

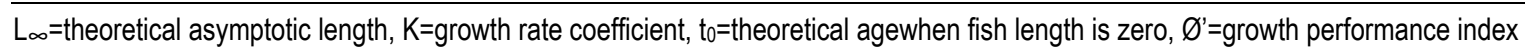

\section{REFERENCES}

Akşıray, F. (1987). A Key to Marine Fishes of Turkey. (in Turkish). İstanbul Üniversitesi Rektörlüğü Yayınları, İstanbul, 811pp.

Aslan, A. (2009). Determination Of Some Haematological And Biochemical Blood Parameters Of The Picarel, Spicara maena (Linnaeus, 1758), In Dardanelles (in Turkish with English abstract). Master thesis. Çanakkale Onsekiz Mart University, Çanakkale, Turkey.

Avşar, D. (1998). Fishery Biology and Population Dynamics. (in Turkish). Çukurova University Fisheries Faculty, Adana, Turkey, 303pp.

Avşar, D., Çiçek, E., Yeldan, H., Manaşırlı, M. \& Mavruk, S. (2007). Otolit morphologies of some Centracanthids (Teleost Fish) distributed in Iskenderun and Mersin Bays. (in Turkish with English abstract). Turkish Journal of Aquatic Life, 5-8(3-5): 116-123.

Bat L., Erdem Y., Ustaoğlu Trıl S. \& Yardım, Ö. (2008). Fish Systematic (in Turkish). Nobel Yayın Dağıtım, Ankara, 270 pp.

Bolognini, L., Domenichetti, F., Grati, F., Polidori, P., Scarcella, G. \& Fabi, G (2013). Weight-length relationships for 20 fish species in the Adriatic Sea.
Turkish Journal of Fisheries and Aquatic Sciences, 13: 555-560. doi: 10.4194/1303-2712-v13_3_21

Borges, T.C., Olim, S. \& Erzini, K. (2003). Weight-length relationship for fish species discarded in commercial fisheries of the Algarve (southern Portugal). Journal of Applied Ichthyology, 19(6):394-396. doi: 10.1111/j.1439-0426.2003.00480.x

Can, A. \& Bilecenoğlu M., 2005. Atlas of Deep Sea Fishes of Turkey (in Turkish). Arkadaş Yayın Evi, Ankara, Turkey, 108pp.

Çelikkale, M.S. (1991). Fish Biology (in Turkish). Karadeniz Technical University College of Marine Science and Technology, Trabzon, Turkey, $286 \mathrm{pp}$.

Çiçek, E. \& Avşar, D. (2010). Growth and Mortality of Spicara smaris (Linnaeus, 1758) Off Karatas Coast (Iskenderun Bay). (in Turkish with English abstract). E-Journal of New World Sciences Academy Ecological Life Sciences, 5(2):126-134. 
Çiçek, E., Avsar, D., Yeldan H. \& Ozutok, M. (2006). Length-weight relationships for 31 teleost fishes caught by bottom trawl net in the Babadillimani Bight (Northeastern Mediterranean. Journal of Applied Ichthyology, 22:290-292. doi: 10.1111/j.1439-0426.2006.00755.x

Çiçek, E., Avşar, D., Yeldan, H. \& Manaşırlı, M. (2007). Population characteristics and growth of Spicara maena (Linnaeus, 1758) inhabiting in Babadillimani Bight (northeastern Mediterranean-Turkey), Internationa Journal of Natural and Engineering Science, 1: 15-18.

Demirel, N. \& Murat Dalkara, E. (2012). Weight-length Relationships of 28 Fish Species in the Sea of Marmara. Turkish Journal of Zoology, 36(6): 785 791. doi:10.3906/zoo-1111-29

Dulcic, J. \& Kraljevic, M. (1996). Weight-length relationship for 40 fish species in the eastern Adriatic (Croatian waters). Fisheries Research, 28(3):243 251. doi: 10.1016/0165-7836(96)00513-9

Dulčić, J., Kraljević, Grbec, B. \& Cetinić, P. (2000). Age, growth and mortality of blotched picarel Spicara maena L. (Pisces: Centracanthidae) in the eastern central Adriatic. Fisheries Research, 48, 69-78. doi: 10.1016/S0165-7836(00)00112-0

Dulčić, J., Pallaoro, A., Cetinic, P., Kraljevic, M., Soldo, A., \& Jardas, I. (2003) Age, growth and mortality of picarel, Spicara smaris L. (Pisces: Centracanthidae), from the eastern Adriatic (Croatian coast). Journal of Applied Ichthyology, 19:10-14. doi: 10.1046/j.1439-0426.2003.00345.x

Ekingen G. (2004). Marine fishes Anatomy of Turkey (in Turkish). T.C. Mersin Üniversitesi Yayınları, Mersin, Turkey, $125 \mathrm{pp}$.

Ercan, H., Yığın, C. \& İşmen, A. (2006). Fecundity of picarel (Spicara smaris L., 1758) in the North Aegean Sea (in Turkish with English abstract). Ege Journal of Fisheries and Aquatic Sciences, 23:413-415.

Gelman, A., Carlin, J.B., Stern, H.S. \& Rubin, D.B. (2004). Bayesian data analysis. Second Edition Chapman and Hall/CRC Texts in Statistical Science.

Gökçe, G., Çekiç, M. \& Filiz, H. (2010). Length-Weight relationships of marine fishes off Yumurtalık Coast (Iskenderun Bay), Turkey. Turkish Journal of Zoology, 34:101-104

Hattour, A., Turki, B. \& Zammouri, N. (1985). Some biological aspects of the species Spicara Flexuosa (Rafinesque, 1810) of Tunisian Waters (in French with English abstract). Bulletin de I'Institut National Scientifique et Technique d'Oceanographie et de Peche Salammbo, 12:143-162.

İşmen, A. (1995). Growth, mortality and yield per recruit model of picare (Spicara smaris L.) on the eastern Turkish Black Sea coast. Fisherie Research, 22:299-308. doi: 10.1016/0165-7836(95)94955-P

İşmen, A., Özen Ö., Altınağaç, U., Özekinci, U. \& Ayaz, A. (2007). Weightlength relationships of 63 fish species in Saros Bay, Turkey. Journal of Applied Ichthyology, 23:707-708. doi: 10.1111/j.1439-0426.2007.00872.x

Jardas, I. (1996). Adriatic Ichthyofauna (in Croatian). SÏkolska knjiga, Zagreb $533 \mathrm{pp}$.

Kalaycl, F., Samsun, N., Bilgin, S. \& Samsun, O. (2007). Length-weigh relationship of 10 fish species caught by bottom trawl and midwater traw from the Middle Black Sea, Turkey. Turkish Journal of Fisheries and Aquatic Sciences, 7: 33-36.

Karakulak, F.S., Erk, H. \& Bilgin, B. (2006). Length-weight relationships for 47 coastal fish species from the northern Aegean Sea, Turkey. Journal of Applied Ichthyology, 22:274-278. doi: 10.1111/j.1439-0426.2006.00736.x

Mater, S., Malkav, S. \& Bayhan, B. (2001). A study on some biological peculiarities of the Picarel (Spicara flexuosa Rafinesque, 1810) distributed in the bay of Izmir (Aegean Sea) (in Turkish with English abstract). Ege Journal of Fisheries and Aquatic Sciences, 18: (1-2) 25-32.
Matic Skoko, S., Kraljevic, M. \& Dulcic, J. (2004). Fecundity of blotched picare Spicara maena L. (Teleostei: Centracanthidae), in the eastern central Adriatic Sea. Acta Adriatica, 45 (2):155-162.

Merella P., Quetglas, A., Alemany, F. \& Carbonell, A. (1997). Length-weight relationship of fishes and cephalopods from the Balearic Islands (western Mediterranean). Naga, The International Center for Living Aquatic Resources Management Quarterly, 20(3/4):66-68.

Miller, P.J. \& Loates, M.J. (1997). Fish of Britain and Europe. Collins Pocket Guide. Harper Collins Publishers, London. 288 pp.

Moutopoulos, D.K. \& Stergiou, K.I. (2002). Length-weight and length-length relationships of fish species of the Aegean Sea (Greece). Journal of Applied Ichthyology, 18(3):200-203 doi:10.1046/j.1439-0426.2002.00281.x

Mytilinieou, C.H., \& Papaconstantinou, C. (1991). Age and growth of Spicara flexuosa (Rafinesque, 1810) (Pisces, Centracanthidae) in the Patraikos gulf (Greece). Scientia Marina, 55(3): 483-490.

Nikolsky, G.W. (1963). The Ecology of Fishes. Acedemic Press. London and New York, 352 pp.

Pauly, D. (1984). Fish population dynamics in tropical waters: a manual for use with programmable calculators ICLARM Studies and Reviews 8, $325 \mathrm{p}$. International Center for Living Aquatic Resources Management, Manila, Philippines.

Pauly, D., \& Munro, J.L. (1984). Once more on the comparison of growth in fish and invertebrates. Fishbyte, 2 (1): $21 \mathrm{p}$.

Petrakis, G. \& Stergiou, K.I. (1995). Weight-length relationships for 33 fish species in Greek waters. Fisheries Research, 21:465-469. doi: 10.1016/0165-7836(94)00294-7

Ricker, W. E. (1975). Computation and Interpretation of Biological Statistics of Fish Populations. Bulletin Fisheries Research Board of Canada, 191, $382 p$.

Rizkalla, S.I. (1997). Age and Growth Studies of Picarels (Spicara flexuosa and Spicara smaris) in the Egyptian Mediterranean Waters. Oebalia, 23:75-86.

Sahin, T. \& Genç, Y. (1999). Some Biological Characteristics of Picarel (Spicara smaris, Linnaeus 1758) in the Eastern Black Sea Coast of Turkey (in Turkish with English abstract). Turkish Journal of Zoology, 23(1): 149155.

Sangun, L., Akamca, E. \& Akar, M. (2007). Weight-length relationships for 39 fish species from the North-Eastern Mediterranean coast of Turkey. Turkish Journal of Fisheries and Aquatic Sciences, 7:37-40.

Soykan, O., İlkyaz, A.T., Metin, G. \&Kınacıgil, H.T. (2010). Growth and Reproduction of Blotched Picarel (Spicara maena Linnaeus, 1758) in the Central Aegean Sea Turkey. Turkish Journal of Zoology, 34:453-459.

Sparre, P. \& Venema, S.C. (1998). Introduction to Tropical Fish Stock Assessment. Part 1: Manual. Food and Agriculture Organization Fisheries Technical Paper, (306/1) Rev.2: 407p.

Tortonese, E., (1986). Centracanthidae. In P.J.P. Whitehead, M.-L. Bauchot, J.-C. Hureau, J. Nielsen and E. Tortonese (eds.) Fishes of the northeastern Atlantic and the Mediterranean Volume II (pp. 908-911), United Nations Educational, Scientific and Cultural Organization, Paris.

Valle, C., Bayle J.T., \& Ramos, A.A. (2003). Weight-length relationships for selected fish species of the western Mediterannean Sea. Journal of Applied Ichthyology, 19:261-262. doi: 10.1046/j.1439-0426.2003.00492.x

Yeldan, H., Avşar, D., Özütok, M. \& Çiçek, E. (2003). Growth and reproduction peculiarities of the picarel (Spicara smaris L., 1758) from the Babadılliman Bight (Silifke-İcel) (in Turkish with English abstract). Ege Journal of Fisheries and Aquatic Sciences, 20(1-2): 35-42 